\title{
Which factors influence the density of birch (Betula pendula Roth) seeds in soil seed banks in temperate woodlands?
}

\author{
Katharina Tiebel ${ }^{1}$ (D)
}

Received: 6 April 2021 / Revised: 13 August 2021 / Accepted: 20 August 2021 / Published online: 1 September 2021

(c) The Author(s) 2021

\begin{abstract}
The natural regeneration of disturbed forest sites is becoming increasingly important due to climate change. Following disturbance events affecting large areas seed trees are often absent from the site, and regeneration solely by means of seed rain may not be successful. In these situations, soil seed banks are an important driver of the regeneration and reforestation of forest sites. The aim of the study was to determine the birch seed density in the soil of birch stands, spruce-birch stands and spruce stands dependent upon the number of seed trees (stands) and upon varying degrees of ground cover using the 'seedling emergence method.' The study revealed a significant link between the quantity of germinated birch seedlings in soil samples and the presence of seed sources. Seedling densities of birch in the different stand categories reached 2644-6414 seedlings per $\mathrm{m}^{2}\left[\mathrm{n} \mathrm{m}^{-2}\right.$ ] in birch stands, 392-759 $\mathrm{n} \mathrm{m}^{-2}$ in spruce-birch stands and 25-122 $\mathrm{n} \mathrm{m}^{-2}$ in pure spruce stands. The density of germinated birch seedlings was also negatively affected by the soil layer. In all stand types, the factors humus thickness, litter cover, moss cover and herb cover had no significant influence on the amount of birch seedlings. Successful rapid regeneration of disturbed sites by means of the birch soil seed bank is guaranteed in cases where birch stands, or at least birch seed trees, were present before the event. The influence of ground cover on the regeneration potential of birch from the soil is negligible.
\end{abstract}

Keywords Silver birch $\cdot$ Picea abies $\cdot$ Propagule bank $\cdot$ Germination $\cdot$ Pioneer tree

\section{Introduction}

The increasing frequency of abiotic and biotic disturbance events like drought, storm, fire, snow damage and insect calamities in the forests of central Europe is resulting in the continuing emergence of disturbed areas (IPCC 2014, 2020). As has been evident in recent years, climate change is taking place and the abiotic and biotic risks will continue to intensify. As a consequence, the problems associated with regenerating the many, and occasionally large-scale, disturbed forest sites will grow. Artificial reforestation is increasingly becoming a problem due to the high financial and human resources required. Instead of planting and

Communicated by Christian Ammer.

Katharina Tiebel

Katharina.Tiebel@tu-dresden.de; Katharina.Tiebel@gmx.de

1 Institute of Silviculture and Forest Protection, Chair of Silviculture, Technische Universität Dresden, Pienner Straße 8, Tharandt, 01737 Tharandt, Germany seeding, the disturbed sites can also be naturally regenerated by means of seed dispersal and soil seed banks (i.e., sources of viable seeds stored in the soil for several years) (Hille Ris Lambers et al. 2005; Hopfensberger 2007; Liu et al. 2019). A rapid regeneration of disturbed forest areas can be achieved by exploiting these succession dynamics (Knocke et al. 2008; Zerbe 2009).

The most common pioneer tree species in the temperate forests of central Europe are Betula pendula Roth, Salix caprea L., Populus tremula L. and Sorbus aucuparia L. (Zerbe 2001), but only silver birch (Betula pendula) is able to build up a persistent soil seed bank (Bakker et al. 1996; Plohak et al. 2020; Tiebel et al. 2018, 2021). Birch can produce 0.3 to 6.5 million seeds, depending on whether it's a non-mast or a mast year (Tiebel et al. 2020). The latter occur every 3 years (Sarvas 1948). In general, seeds of pioneer tree species are dispersed over long distances, but their distribution is not endless (Gage and Cooper 2005; Jordano and Schupp 2000; Tiebel et al. 2019, 2020). The mean dispersal distance of wind dispersed birch seed varies between 40 and $360 \mathrm{~m}$ (Huth 2009; Tiebel et al. 2020). The ability of birch 
to establish a soil seed bank persisting for 5 to more than 13 years is an advantage for the species (Granström 1987; Skoglund and Verwijst 1989; Tiebel et al. 2021). Seedlings can recruit from soil seed banks, even after seed trees have already disappeared from a particular area or a seed rain cannot reach the area because of limited seed dispersal distances (see Fenner 1985; Tiebel et al. 2017, 2020).

The soil seed bank is naturally activated by disturbances like storm and fire, and by the activities of animals (e.g., wild boars). 'Activated' means the buried and viable seeds are stimulated to germinate due to changing environmental conditions (Bossuyt and Hermy 2001; Pugnaire and Lozano 1997). Therefore, soil seed banks are an important driver of the succession dynamics of ecosystems and of the regeneration and reforestation of disturbed forest sites (Hille Ris Lambers et al. 2005; Putz and Appanah 1987; Weerasinghe et al. 2019).

The findings obtained in relation to birch seed densities in soil vary between studies (Tiebel et al. 2018). Reasons revealed for differences in soil seed bank compositions and seed quantities are the soil type, soil moisture, $\mathrm{pH}$ value, storage depth and the light conditions on the ground (Hille Ris Lambers et al. 2005; Ma et al. 2017; Narwal et al. 2008; Skoglund and Verwijst 1989; Van et al. 2005). Little is known about how the factor ground cover, such as litter cover, moss cover, grass cover and humus thickness, influence seed input or the storability of birch seeds in the soil seed bank. The factors are subject to debate and clarification is still required in relation to some aspects (Baskin and Baskin 1998). Facelli and Pickett (1991) and Yan et al. (2013) described the litter layer as a physical barrier preventing seeds from reaching the soil (Facelli and Pickett 1991). Bueno and Baruch (2011) and Gang et al. (2015), by contrast, found that litter does not prevent seeds from reaching the soil. The impact of vegetation cover on the amount of seeds in the soil, whether positive or negative, is not yet known for all species (Baskin and Baskin 1998), particularly for birch, but it would appear plausible that it acts as an additional barrier. Tiebel et al. (2018) identified the number of birch seed trees as another factor possibly influencing birch seed density in the soil. The quantity of seed sources (from single admixed seed trees to pure stands of seed trees) is another factor that has not yet been considered in any study of soil seed banks, but would appear to be an important influencing factor.

The aim of the investigation presented here was to determine the effect of ground cover and seed tree number on the density of silver birch seed in the humus and mineral soil layers in temperate woodlands. The following two hypotheses were formulated: (1) A higher density of birch seeds in all soil layers is due to higher numbers of seed trees, with the result that a soil seed bank with sufficiently high potential for regeneration after disturbance will develop in pure and mixed birch forests. (2) Independent of the quantity of seed sources, the number of buried viable birch seeds decreases with increasing ground cover density and humus thickness.

\section{Materials and methods}

\section{Study area}

The study was located at colline and submontane altitudes in the Tharandter Forest $\left(50^{\circ} 57^{\prime} \mathrm{N}\right.$ and $\left.13^{\circ} 30^{\prime} \mathrm{E}\right)$ in the German federal state Saxony, which is situated between 200 and $460 \mathrm{~m}$ above sea level, on the northern edge of the eastern Ore Mountains [Erzgebirge] (Fiedler and Hofmann 1978). The area is located at the transition between the oceanic-influenced climate of the central German mountain and hill country and the continental inland climate (Nebe 1982). The mean annual temperature varies between 7.3 and $7.7^{\circ} \mathrm{C}$ and the mean annual precipitation between 819 and $850 \mathrm{~mm}$ (Goldberg et al. 2002). The geology of the region has given rise to medium to deep brown soils that predominate on the forest sites, as well as dry sands and podzols with low nutrient contents and silty brown earths (Nebe 1982; Schwanecke and Kopp 1996). The woodland comprises mainly single-layered, even-aged Norway spruce forests (Picea abies (L.) Karst.). Humans played an extensive role in introducing spruce throughout the Tharandter Forest, in pure and mixed stands, in the early nineteenth century to meet the wood requirements of the local people. The main form of management in the past was clearcutting in small strips (Schwiebus and Baums 2002). Since the 1980s foresters have been restoring conifer forests to natural mixed stands in keeping with the goal of sustainable forest management. The predominant potential natural vegetation types are Luzulo-Fagetum and Galio ordorati-Fagetum forests (Menzer et al. 2010).

\section{Study sites}

Soil core samples were taken from nine study sites in the Tharandter Forest. The study sites were divided into three stand types differentiated by the species composition of the canopy (Table 1). The stand types chosen were stands of Betula pendula (birch stands), stands of Picea abies (L.) Karst. with a small number of admixed $B$. pendula (spruce-birch stands) and stands of Picea abies with only one isolated $B$. pendula tree within a radius of more than $100 \mathrm{~m}$ (spruce stands). It was not possible to rule out the possibility of the removal of additional seed trees from each of the study sites in the years before the study and, correspondingly, the continued presence of their viable seeds in the soil. To address this, the stand types selected for the study differed vastly in terms of the number of birch seed trees present (Table 1). 
Table 1 Characteristics of the study sites and the influencing factors measured (*information from forest inventory data)

\begin{tabular}{|c|c|c|c|c|c|c|c|c|c|}
\hline \multirow{3}{*}{$\begin{array}{l}\text { Location } \\
\text { Stand type } \\
\text { Study site } \\
\text { no. }\end{array}$} & \multicolumn{9}{|c|}{ Tharandter forest } \\
\hline & \multicolumn{3}{|l|}{ Birch stand } & \multicolumn{3}{|c|}{ Spruce-birch stand } & \multicolumn{3}{|l|}{ Spruce stand } \\
\hline & 1 & 2 & 3 & 4 & 5 & 6 & 7 & 8 & 9 \\
\hline $\begin{array}{l}\text { Dominant } \\
\text { tree spe- } \\
\text { cies }\end{array}$ & $\begin{array}{l}\text { Betula } \\
\quad \text { pendula }\end{array}$ & $\begin{array}{l}\text { Betula } \\
\quad \text { pendula }\end{array}$ & $\begin{array}{l}\text { Betula } \\
\quad \text { pendula }\end{array}$ & Picea abies & Picea abies & Picea abies & Picea abies & Picea abies & Picea abies \\
\hline \multirow{3}{*}{$\begin{array}{l}\text { Admixed } \\
\text { tree spe- } \\
\text { cies }\end{array}$} & $\begin{array}{l}\text { Larix } \\
\quad \text { decidua }\end{array}$ & $\begin{array}{l}\text { Larix } \\
\quad \text { decidua }\end{array}$ & Picea abies & $\begin{array}{l}\text { Betula } \\
\quad \text { pendula }\end{array}$ & $\begin{array}{l}\text { Betula } \\
\quad \text { pendula }\end{array}$ & $\begin{array}{l}\text { Larix } \\
\text { decidua }\end{array}$ & & $\begin{array}{l}\text { Larix } \\
\quad \text { decidua }\end{array}$ & Larix decidua \\
\hline & & & & $\begin{array}{l}\text { Fagus syl- } \\
\text { vatica }\end{array}$ & $\begin{array}{l}\text { Larix } \\
\quad \text { decidua }\end{array}$ & $\begin{array}{l}\text { Pinus syl- } \\
\text { vestris }\end{array}$ & & $\begin{array}{l}\text { Pinus syl- } \\
\text { vestris }\end{array}$ & \\
\hline & & & & & & $\begin{array}{l}\text { Betula } \\
\quad \text { pendula }\end{array}$ & & & \\
\hline \multicolumn{10}{|c|}{ Stand characteristic } \\
\hline $\begin{array}{l}\text { Tree age } \\
\text { [years]* }\end{array}$ & $62-70$ & $30-35$ & $61-75$ & $93-111$ & $69-74$ & $86-95$ & $59-74$ & $47-59$ & 98 \\
\hline $\begin{array}{l}\text { Number of } \\
\text { birch seed } \\
\text { trees in } \\
\text { study site }\end{array}$ & 8 & 6 & 6 & 1 & 1 & 1 & 0 & 0 & 0 \\
\hline \multicolumn{10}{|c|}{ Basal area $\left[\mathrm{m}^{2} / \mathrm{ha}\right]$} \\
\hline $\begin{array}{l}\text { Betula pen- } \\
\quad \text { dula }\end{array}$ & 35 & 23 & 24 & 3 & 2 & 5 & - & - & - \\
\hline Pice abies & - & - & 4 & 44 & 35 & 30 & 49 & 44 & 38 \\
\hline $\begin{array}{l}\text { Pinus sylves- } \\
\quad \text { tris }\end{array}$ & - & - & - & - & - & 1 & - & 3 & - \\
\hline $\begin{array}{l}\text { Larix } \\
\quad \text { decidua }\end{array}$ & 4 & 1 & - & - & 3 & 9 & - & 1 & 1 \\
\hline $\begin{array}{l}\text { Fagus syl- } \\
\text { vatica }\end{array}$ & - & - & - & 1 & - & - & - & - & - \\
\hline \multicolumn{10}{|l|}{ Height $[\mathrm{m}]$} \\
\hline $\begin{array}{l}\text { Betula pen- } \\
\quad \text { dula }\end{array}$ & $27.6 \pm 1.86$ & $22.46 \pm 1.75$ & $27.6 \pm 2.43$ & $25.6 \pm 2.35$ & $26.2 \pm 1.63$ & $27.9 \pm 1.88$ & - & - & - \\
\hline Pice abies & - & - & $19.5 \pm 6.79$ & $29.6 \pm 1.03$ & $28.2 \pm 0.98$ & $29.0 \pm 1.65$ & $25.1 \pm 1.46$ & $26.0 \pm 0.77$ & $28.8 \pm 1.07$ \\
\hline $\begin{array}{l}\text { Pinus sylves- } \\
\text { tris }\end{array}$ & - & - & - & - & - & $28.8 \pm 0.00$ & - & $23.8 \pm 3.71$ & - \\
\hline $\begin{array}{l}\text { Larix } \\
\quad \text { decidua }\end{array}$ & $28.0 \pm 1.97$ & $20.6 \pm 0.00$ & - & - & $28.7 \pm 0.81$ & $28,7 \pm 1.81$ & - & $29.2 \pm 0.00$ & $27.5 \pm 0.00$ \\
\hline $\begin{array}{l}\text { Fagus syl- } \\
\text { vatica }\end{array}$ & - & - & - & $26.6 \pm 0.00$ & - & - & - & - & - \\
\hline \multicolumn{10}{|c|}{ Diameter at breast height [cm] } \\
\hline $\begin{array}{l}\text { Betula pen- } \\
\quad \text { dula }\end{array}$ & $32.5 \pm 5.95$ & $25.4 \pm 3.21$ & $33.4 \pm 4.45$ & $41.8 \pm 7.88$ & $35.4 \pm 2.97$ & $39.0 \pm 7.85$ & $31.6 \pm 3.76$ & $35.5 \pm 4.05$ & $45.3 \pm 6.37$ \\
\hline Pice abies & - & - & $33.5 \pm 11.20$ & $39.4 \pm 7.07$ & $37.9 \pm 1.73$ & $36.4 \pm 6.95$ & - & $29.5 \pm 6.17$ & - \\
\hline $\begin{array}{l}\text { Pinus sylves- } \\
\quad \text { tris }\end{array}$ & - & - & - & - & - & $50.5 \pm 0.00$ & - & $47.3 \pm 0.00$ & $34.5 \pm 0,00$ \\
\hline $\begin{array}{l}\text { Larix } \\
\text { decidua }\end{array}$ & $38.6 \pm 3.83$ & $24.1 \pm 0.00$ & - & - & $38.8 \pm 4.54$ & $36.0 \pm 7.12$ & - & - & - \\
\hline $\begin{array}{c}\text { Fagus syl- } \\
\text { vatica }\end{array}$ & - & - & - & $65.2 \pm 0.00$ & - & - & - & - & - \\
\hline \multicolumn{10}{|c|}{ Soil characteristics* } \\
\hline Topography & Flat & $\begin{array}{l}\text { Flat to gen- } \\
\text { tly sloping }\end{array}$ & Flat & Flat & Flat & $\begin{array}{l}\text { Flat to gen- } \\
\text { tly sloping }\end{array}$ & Flat & $\begin{array}{l}\text { Flat to gen- } \\
\text { tly sloping }\end{array}$ & $\begin{array}{l}\text { Flat to gently } \\
\text { sloping }\end{array}$ \\
\hline
\end{tabular}


Table 1 (continued)

\begin{tabular}{|c|c|c|c|c|c|c|c|c|c|}
\hline \multirow{3}{*}{$\begin{array}{l}\text { Location } \\
\text { Stand type } \\
\text { Study site } \\
\text { no. }\end{array}$} & \multicolumn{9}{|c|}{ Tharandter forest } \\
\hline & \multicolumn{3}{|l|}{ Birch stand } & \multicolumn{3}{|c|}{ Spruce-birch stand } & \multicolumn{3}{|c|}{ Spruce stand } \\
\hline & 1 & 2 & 3 & 4 & 5 & 6 & 7 & 8 & 9 \\
\hline Nutrition & $\begin{array}{c}\text { Moderate } \\
\text { nutrient } \\
\text { content }\end{array}$ & $\begin{array}{l}\text { Low-to- } \\
\text { moderate } \\
\text { nutrient } \\
\text { content }\end{array}$ & $\begin{array}{c}\text { Moderate } \\
\text { nutrient } \\
\text { content }\end{array}$ & $\begin{array}{c}\text { Moderate } \\
\text { nutrient } \\
\text { content }\end{array}$ & $\begin{array}{c}\text { Moderate } \\
\text { nutrient } \\
\text { content }\end{array}$ & $\begin{array}{l}\text { Low-to- } \\
\text { moderate } \\
\text { nutrient } \\
\text { content }\end{array}$ & $\begin{array}{c}\text { Moderate } \\
\text { nutrient } \\
\text { content }\end{array}$ & $\begin{array}{l}\text { Low-to- } \\
\text { moderate } \\
\text { nutrient } \\
\text { content }\end{array}$ & $\begin{array}{c}\text { Moderate } \\
\text { nutrient } \\
\text { content }\end{array}$ \\
\hline Moisture & Moist to wet & Moist to wet & Moist to wet & Moist to wet & Moist to wet & Moist to wet & $\begin{array}{c}\text { Moist to } \\
\text { wet }\end{array}$ & Moist to wet & Moist to wet \\
\hline \multicolumn{10}{|c|}{ Vegetation cover } \\
\hline $\begin{array}{l}\text { Mean litter } \\
\text { and humus } \\
\text { thickness } \\
{[\mathrm{cm}]}\end{array}$ & $3.0 \pm 0.65$ & $2.6 \pm 0.82$ & $3.2 \pm 1.01$ & $4.2 \pm 1.37$ & $4.0 \pm 1.31$ & $6.2 \pm 1.21$ & $6.6 \pm 3.38$ & $5.6 \pm 1.06$ & $5.6 \pm 0.83$ \\
\hline \multicolumn{10}{|c|}{ Mean degree of cover of } \\
\hline $\begin{array}{c}\text { Litter layer } \\
{[\%]}\end{array}$ & $51 \pm 27.9$ & $77 \pm 23.1$ & $72 \pm 10.1$ & $18 \pm 19.0$ & $24 \pm 23.2$ & $70 \pm 25.4$ & $36 \pm 37.0$ & $62 \pm 47.7$ & $5 \pm 7.7$ \\
\hline $\begin{array}{c}\text { Moss layer } \\
{[\%]}\end{array}$ & $50 \pm 45.8$ & $38 \pm 44.5$ & $90 \pm 20.7$ & $96 \pm 8.3$ & $100 \pm 0.0$ & $54 \pm 46.5$ & $90 \pm 20.7$ & $42 \pm 48.9$ & $100 \pm 0.0$ \\
\hline $\begin{array}{c}\text { Herb layer } \\
{[\%]}\end{array}$ & $41 \pm 37.7$ & $2.8 \pm 3.8$ & $12 \pm 20.1$ & $0.2 \pm 0.4$ & $6 \pm 5.1$ & $18 \pm 32.3$ & $0 \pm 0.0$ & $0.4 \pm 0.8$ & $1.0 \pm 0.0$ \\
\hline
\end{tabular}

In the autumn prior to the study, the birch seed trees in the Tharandter Forest produced many catkins. It is not possible, however, to state definitively whether it was a mast or a nonmast year, because seeds were not trapped and counted.

Study site 1-birch stand: A 0.9 ha, single-layered, managed, 62-70-year-old birch stand was selected for the study. Larix decidua was also present in the stand. There were eight birch seed trees within the study plot. The canopy of the stand was closed and the basal area for both tree species was $39 \mathrm{~m}^{2} \mathrm{ha}^{-1}$. The heights and diameters of the birch seed trees were $27.6 \pm 1.86 \mathrm{~m}$ and $32.5 \pm 5.95 \mathrm{~cm}$, respectively (Table 2). The soils were mainly moist to wet, with a moderate nutrient content and flat topography. Only sporadic natural regeneration of spruce was observed in the shrub layer (0.8-1 $\mathrm{m}$ in height). The soil surface was covered mainly by grass and herbs (41\%) and moss (50\%). No bare ground was observed. The litter was composed of larch needles and birch leaves, which covered $51 \%$ of the ground. The thickness of the litter and humus layer was $3.0 \pm 0.65 \mathrm{~cm}$.

Study site 2-birch stand: The second birch stand covered an area of 0.3 ha, the trees were 30-35 years old and the stand single-layered with a light canopy. The stand had a basal area of $25 \mathrm{~m}^{2} \mathrm{ha}^{-1}$ and was mixed with Larix decidua $\left(1 \mathrm{~m}^{2} \mathrm{ha}^{-1}\right)$. The birch trees were $22.46 \pm 1.75 \mathrm{~m}$ in height and had a diameter at breast height of $25.4 \pm 3.21 \mathrm{~cm}$ (Table 2). The study plot contained six birch seed trees. On
Table 2 GLMM results for viable Betula pendula seeds in the soil samples from the different stand types and soil layers $(f-$ fixed effects, $r$ - random effects, n.s. - not significant, soil layer $0-5 \mathrm{~cm}$ - upper mineral soil layer of 0 to $5 \mathrm{~cm}$ soil depth, soil layer 5-10 cm - lower mineral soil layer of 5 to $10 \mathrm{~cm}$ soil depth, $\mathrm{SD}$ - standard deviation).

\begin{tabular}{|c|c|c|c|c|c|c|c|c|}
\hline Effects & Factor & Estimate & Std. error & $z$-value & $p$-value & & Variance & SD \\
\hline Intercept & $\mathrm{f}$ & 2.545 & 0.836 & 3.04 & 0.002 & $* *$ & & \\
\hline Spruce-birch stand & $\mathrm{f}$ & -1.953 & 0.437 & -4.47 & 0.000 & $* * *$ & & \\
\hline Spruce stand & $\mathrm{f}$ & -3.956 & 0.693 & -5.71 & 0.000 & $* * *$ & & \\
\hline Soil layer $0-5 \mathrm{~cm}$ & f & -2.446 & 0.298 & -8.21 & 0.000 & $* * *$ & & \\
\hline Soil layer 5-10 cm & $\mathrm{f}$ & -2.978 & 0.337 & -8.83 & 0.000 & $* * *$ & & \\
\hline Humus thickness & $\mathrm{f}$ & 0.033 & 0.111 & 0.31 & 0.760 & n.s & & \\
\hline Moss cover & $\mathrm{f}$ & 0.007 & 0.006 & 1.30 & 0.192 & n.s & & \\
\hline Litter cover & $\mathrm{f}$ & 0.001 & 0.007 & 0.14 & 0.890 & n.s & & \\
\hline Herb cover & $\mathrm{f}$ & 0.006 & 0.007 & 0.89 & 0.373 & n.s & & \\
\hline Study site & $\mathrm{r}$ & & & & & & 0.000 & 0.001 \\
\hline Soil core & $\mathrm{r}$ & & & & & & 0.140 & 0.374 \\
\hline
\end{tabular}

The reference stand type (intercept) is the birch stand 
this flat to gently sloping study site, natural regeneration of spruce, beech and rowan formed the shrub layer, but young trees occurred only occasionally. The herb layer consisted of spring grass and ferns (3\%). Moss cover was 38\% and birch litter covered $77 \%$ of the moist to wet soil, which had a low-to-moderate nutrient content. The litter and humus was $2.0 \pm 4.14 \mathrm{~cm}$ thick.

Study site 3-birch stand: The third birch stand was a 61-75-year-old stand, partly two-layered, managed, with admixed Picea abies $\left(4 \mathrm{~m}^{2} \mathrm{ha}^{-1}\right)$. The shrub layer consisted wholly of the second tree layer made up of spruce and alder (30\% coverage). Betula pendula had a basal area of $24 \mathrm{~m}^{2} \mathrm{ha}^{-1}$, a height of $27.6 \pm 2.43 \mathrm{~m}$ and a diameter at breast height of $33.4 \pm 4.45 \mathrm{~cm}$ (Table 2). There were six birch seed trees within the study plot. The stand was lightly stocked and the terrain flat. The soils were moist to wet with a moderate nutrient content. Grass (12\%) and moss (90\%) covered the ground. The litter and humus thickness was $3.2 \pm 1.01 \mathrm{~cm}$, and contained mainly birch and alder leaves as well as spruce needles. The average litter cover was $72 \%$.

Study site 4-spruce-birch stand: A 6.5 ha, single-layered, managed, 93-111-year-old spruce-birch stand was selected for the study. Betula pendula $\left[3 \mathrm{~m}^{2} \mathrm{ha}^{-1}\right]$ and Fagus sylvatica $\left[1 \mathrm{~m}^{2} \mathrm{ha}^{-1}\right]$ were admixed in the stand with Picea abies $\left[44 \mathrm{~m}^{2} \mathrm{ha}^{-1}\right]$ the dominant tree species. There was only one birch seed tree within the study plot of $20 \mathrm{~m} \times 20 \mathrm{~m}$ within the study site. The canopy of the stand was closed. The heights and diameters of the birch seed trees in the stand were $25.6 \pm 2.35 \mathrm{~m}$ and $41.8 \pm 7.88 \mathrm{~cm}$, respectively, and $29.6 \pm 1.03 \mathrm{~m}$ and $39.4 \pm 7.07 \mathrm{~cm}$ in the case of the spruce trees (Table 2). The soils were mainly moist to wet with a moderate nutrient content and flat topography. Only sporadic natural regeneration of spruce, rowan and beech was observed in the shrub layer. In the spring moss covered $96 \%$ of the soil surface. No herbs or bare ground were detected. The litter was composed of spruce needles and birch leaves, which covered $18 \%$ of the ground. The thickness of the litter and humus layer was $4.2 \pm 1.37 \mathrm{~cm}$.

Study site 5-spruce-birch stand: The second spruce-birch stand covered an area of 2.9 ha. The stand was 69-74 years old and single-layered with a closed canopy. The stand basal area was $40 \mathrm{~m}^{2} \mathrm{ha}^{-1}$, with Betula pendula $\left(5 \mathrm{~m}^{2} \mathrm{ha}^{-1}\right)$ and Larix decidua $\left(1 \mathrm{~m}^{2} \mathrm{ha}^{-1}\right)$ mixed in. The birch trees in the stand were $27.9 \pm 1.88 \mathrm{~m}$ in height and had a diameter at breast height of $39.0 \pm 7.85 \mathrm{~cm}$ (Table 2). Only one birch seed tree grew in the study plot in the stand. Natural regeneration of rowan and beech (10\%) formed the shrub layer of this flat study site. The herb layer consisted of maidens of rowan, beech and fir as well as grass $(6 \%)$. The moist to wet soil had a moderate nutrient content and a moss cover of $100 \%$ and litter cover of $24 \%$. The litter and humus was $4.0 \pm 1.31 \mathrm{~cm}$ thick.
Study site 6-spruce-birch stand: The third spruce-birch stand was an 86-95-year-old, single-layered managed stand, with admixed Larix decidua $\left(9 \mathrm{~m}^{2} \mathrm{ha}^{-1}\right)$, Pinus sylvestris (1 $\left.\mathrm{m}^{2} \mathrm{ha}^{-1}\right)$ and Betula pendula $\left(5 \mathrm{~m}^{2} \mathrm{ha}^{-1}\right)$. The Picea abies had a basal area of $30 \mathrm{~m}^{2} \mathrm{ha}^{-1}$, a height of $28.8 \pm 1.07 \mathrm{~m}$ and a diameter at breast height of $45.3 \pm 6.37 \mathrm{~cm}$ (Table 2). The measured height and diameter at breast height of Betula pendula were $27.9 \pm 1.88 \mathrm{~m}$ and $39.0 \pm 7.85 \mathrm{~cm}$, respectively. The stand was characterized by a closed canopy, low-tomoderate nutrient content of the soil and moist to wet conditions. There was one birch seed tree within the study plot. This site was flat to gently sloping. Naturally regenerated beech and spruce $(5 \%)$ as well as grass $(10 \%)$ were recorded in the herb layer. There was no shrub layer. Moss covered $54 \%$ of the ground. The measured litter and humus thickness was $6.2 \pm 1.21 \mathrm{~cm}$, contained mainly spruce and larch needles and covered $70 \%$ of the ground.

Study site 7-spruce stand: A 4.5 ha, single-layered, managed, 59-74-year-old spruce stand was selected for the study. The canopy of the stand was dense and the basal area of Picea abies was $49 \mathrm{~m}^{2} \mathrm{ha}^{-1}$. The heights and diameters of the spruce trees were $25.1 \pm 1.46 \mathrm{~m}$ and $31.6 \pm 3.76 \mathrm{~cm}$, respectively (Table 2). The nearest birch seed tree was $80 \mathrm{~m}$ away, next to a forest road. The soils were mainly moist to wet with a moderate nutrient content and the topography was flat. No species were detected in the shrub layer. Only moss and needles covered the soil surface, at $90 \%$ and $36 \%$, respectively. No herbs and bare ground were detected. The litter and humus thickness was $6.6 \pm 3.38 \mathrm{~cm}$.

Study site 8 -spruce stand: The second managed spruce stand covered an area of 3.1 ha was 47-59 years old and single-layered with a closed canopy. The stand, with a basal area of $48 \mathrm{~m}^{2} \mathrm{ha}^{-1}$, was mixed with Pinus sylvestris (1 $\left.\mathrm{m}^{2} \mathrm{ha}^{-1}\right)$ and Larix decidua $\left(3 \mathrm{~m}^{2} \mathrm{ha}^{-1}\right)$. The spruce trees were $26.0 \pm 0.77 \mathrm{~m}$ in height and had a diameter at breast height of $35.5 \pm 4.05 \mathrm{~cm}$ (Table 2). The nearest birch seed tree was detected at a distance of $80 \mathrm{~m}$ from the stand. There was no shrub or herb layer ( $0.4 \%)$ present. Only moss (42\%) and spruce needles $(62 \%)$ covered the moist to wet soil of low-to-moderate nutrient content. The litter and humus was $5.6 \pm 1.06 \mathrm{~cm}$ thick.

Study site 9-spruce stand: The third spruce stand was an even-aged (98 years), single-layered managed stand, admixed with Larix decidua $\left(1 \mathrm{~m}^{2} \mathrm{ha}^{-1}\right)$. Picea abies had a basal area of $38 \mathrm{~m}^{2} \mathrm{ha}^{-1}$, height of $28.8 \pm 1.07 \mathrm{~m}$ and a diameter at breast height of $45.3 \pm 6.37 \mathrm{~cm}$ (Table 2). The stand had a closed canopy. The nearest birch seed tree was $80-100 \mathrm{~m}$ from the study site, situated on a forest road. This site was flat to gently sloped, and the soil of moderate nutrient content and moist to wet. Naturally regenerated rowan, beech, birch and spruce seedlings (1\%) were recorded in the herb layer, but not in the shrub layer. Moss covered 100\% 
of the ground. The litter and humus was $5.6 \pm 0.83 \mathrm{~cm}$ thick and covered $5 \%$ of the ground.

The three study sites (replicates) associated with each stand type were characterized by somewhat comparable soil conditions and stand characteristics to ensure that the differences in the birch seed banks were due to the contrasting stand compositions and corresponding ground cover. The soil thickness varied from $15 \mathrm{~cm}$ to more than $1 \mathrm{~m}$.

\section{Data collection}

Seed bank sampling took place in March 2020, after the winter and before the onset of seed germination. On each study site, five soil core samples were taken from within a square plot of $20 \mathrm{~m} \times 20 \mathrm{~m}$, four samples at the corners and one sample at the plot center. All 45 cylindrical soil core samples had a diameter of $10.2 \mathrm{~cm}\left(81.92 \mathrm{~cm}^{2}\right)$ and reached a depth of $10 \mathrm{~cm}$ into the mineral soil. Before the samples were taken, the humus thickness and the degree of cover of litter, moss and herbs, including grass, were recorded at each soil core sampling area (Table 1).

The soil core samples were subdivided into three layers: humus and litter, upper mineral soil layer $(0-5 \mathrm{~cm})$ and lower mineral soil layer $(5-10 \mathrm{~cm})$. This resulted in a total of 135 soil samples for the study. The soil samples were stored dry for 3 days in the cold greenhouse and then sieved (mesh size of $4 \mathrm{~mm} \times 9 \mathrm{~mm}$ ) to remove root fragments and stones from the samples (Gross 1990; Olano et al. 2002). Silver birch produces very small and winged seeds (1.5-2.0 $\mathrm{mm}$ in size), lacking dormancy (Atkinson 1992; Brouwer and Stählin 1975; Zerbe 2001). The samples were transferred onto trays, applied in a layer of $3 \mathrm{~cm}$ fill height. If the height of the samples in the trays was too low (less than $1 \mathrm{~cm}$ ), sterile sand was first poured onto the tray and then the soil sample was added to the sand. The trays were placed in a cold greenhouse exposed to seasonally dependent outdoor temperatures and the day-night light regime. The soil was kept continuously moist through regular watering. The frequency of watering depended on the temperature, air humidity and sunlight in the cold greenhouse. The trays were randomly rearranged every 3 weeks to account for spatial light and temperature variations in the greenhouse (Weerasinghe et al. 2019). Additional control trays with sterilized sand were used to check for subsequent seed input in the cold greenhouse (contamination) over the duration of the study period. Every 2 weeks the number of successfully germinated seeds was recorded and these were then removed. This means of determining the number of viable seeds in the soil is referred to as the 'seedling emergence method' (Falinska 1999). The species of the emerged seedlings was determined only for trees. If the number of germinating seeds stagnated, the soil samples were allowed to dry, mixed and watered again. The investigation ended with the conclusion of the vegetation period in autumn.

During soil sampling, the basal areas $\left[\mathrm{m}^{2} \mathrm{ha}^{-1}\right]$ were recorded for all of the study sites using the angle count sample (Kramer and Akça 2002). To determine the heights and diameters, a maximum of five individuals of each counted tree species were assessed using the angle count sample.

The vegetation records were made in the $20 \mathrm{~m} \times 20 \mathrm{~m}$ plots according to Londo (1975, cited in Dierschke 1994). The coverage of the moss, herb and shrub layers was recorded as a percent for all species in the layer combined (=groups), not for each species individually.

\section{Statistical analysis}

The number of emerged birch seedlings per soil sample of $81.92 \mathrm{~cm}^{2}$ was converted to density per $\mathrm{m}^{2}\left[\mathrm{n} \mathrm{m}^{-2}\right]$ to render the results comparable with the findings of other studies.

The data distribution was negative binomial. Differences in the not-normally distributed birch seed densities between study sites within the stand types (birch stand, spruce-birch stand, spruce stand) were analyzed using the Kruskal-Wallis $H$-test and then the Mann-Whitney $U$-test with a Bonferroni correction as a post hoc test (Zar 2010).

A mixed modeling approach was used due to the nested experimental design. The nested random effects in the models were the study sites and soil samples. The aim was to prove the effect of ground cover and seed tree number on the accumulation of silver birch seeds in the soil seed bank. Generalized linear mixed models (GLMM) with mean values were applied to the negative binomial continuous response variable (germinated birch seeds) to verify the relationship between the germinated birch seeds in the trays and the fixed effects: stand type (categorical variable), soil layer (categorical variable), humus thickness (continuous variable), and the degree of cover of litter, moss and herbs (continuous variable) (Zuur et al. 2009). The interaction between the fixed effects was also tested. The GLMM were computed using the software R (version 3.3.2) (R Core Team 2014) and the glmmADMB package (version 0.8.3.3.) with the automatic differentiation model builder (ADMB) (Bolker et al. 2012; Wallraf and Wagner 2019). Model fitting and selection was performed manually in a stepwise backward approach, based on AIC values and ANOVA model comparisons (Wallraf and Wagner 2019). The normal distribution and homoscedasticity of model residuals were visually checked and confirmed with $Q-Q$ plots and plots of residual dispersion from fitted models, respectively (Zuur et al. 2009; Wallraf and Wagner 2019). 


\section{Results}

In the experiment, $1,544,553$ weed seedlings germinated per $\mathrm{m}^{2}\left[\mathrm{n} \mathrm{m}^{-2}\right](12,619$ seedlings per sample $)$ over the whole study period. The only tree seedlings to emerge were Betula pendula, with a total of $79,187 \mathrm{n} \mathrm{m}^{-2}$ seedlings (647 seedlings per sample) recorded in the soil samples. Birch seedlings emerged from all of the soil samples taken from all of the study sites (Fig. 1). The GLMM results showed a significant influence of stand type (GLMM: $z=-1.953$ and $-3.956, p=0.000$ ) on the germinated birch seedlings (Table 2). Soil sample cores taken from birch stands contained the highest mean densities of birch seedlings $\left(2,644-6,414 \mathrm{n} \mathrm{m}^{-2}\right)$, while samples from the spruce stands contained the lowest mean seedling densities $\left(25-122 \mathrm{n} \mathrm{m}^{-2}\right)$. The birch seedling densities revealed no significant differences across the three study sites within each stand type (pairwise Mann-Whitney $U$-test: $p$-value $>0.05$ ).

The density of germinated birch seedlings was negatively affected by the soil layer (GLMM: $z=-2.446$ and $-2.978, p$-value $=0.000)$ (Table 2). Birch seedlings were always present in high numbers in the litter and humus layers (Fig. 2). The density ranged from a mean seedling number of $24 \mathrm{n} \mathrm{m}^{-2}$ in the spruce stand to $6022 \mathrm{n} \mathrm{m}^{-2}$ in the birch stand. Usually no, or only very few, birch seedlings were detected in the lower mineral soil layers, except in the birch stands, where $245 \mathrm{n} \mathrm{m}^{-2}$ and $318 \mathrm{n} \mathrm{m}^{-2}$ seedlings occurred up to $10 \mathrm{~cm}$ soil depth.

The factors humus thickness, litter cover, moss cover and herb cover had no significant influence on the amount of germinated birch seedlings in the soil samples (GLMM $z=0.033,0.001,0.007, \& 0.006, p>0.192)$. The interactions

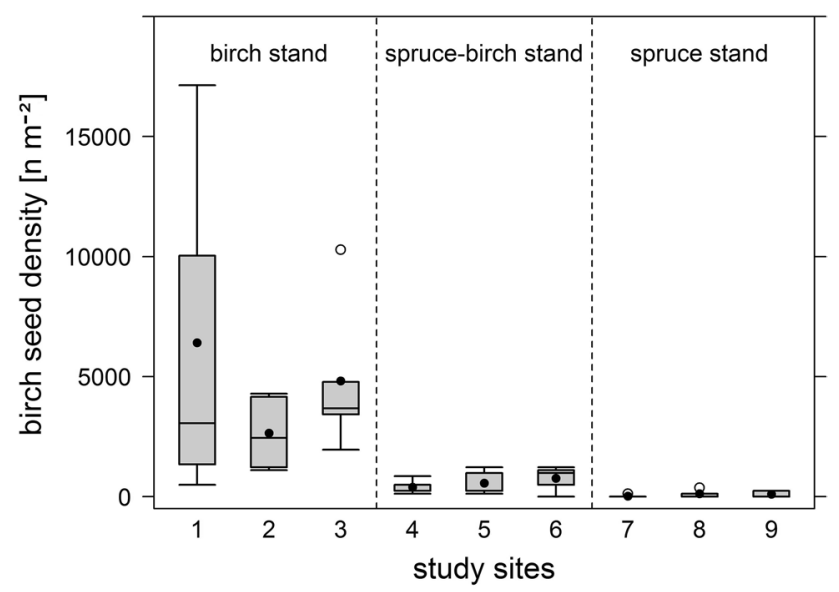

Fig. 1 Boxplot showing viable Betula pendula seed densities $\left[\mathrm{n} \mathrm{m}^{-2}\right]$ in the soil seed banks (litter and mineral soil layers) taken from different study sites within the three stand types investigated. Black lines within the boxes indicate the medians, black circles within the boxes indicate mean values and the white circles indicate outliers

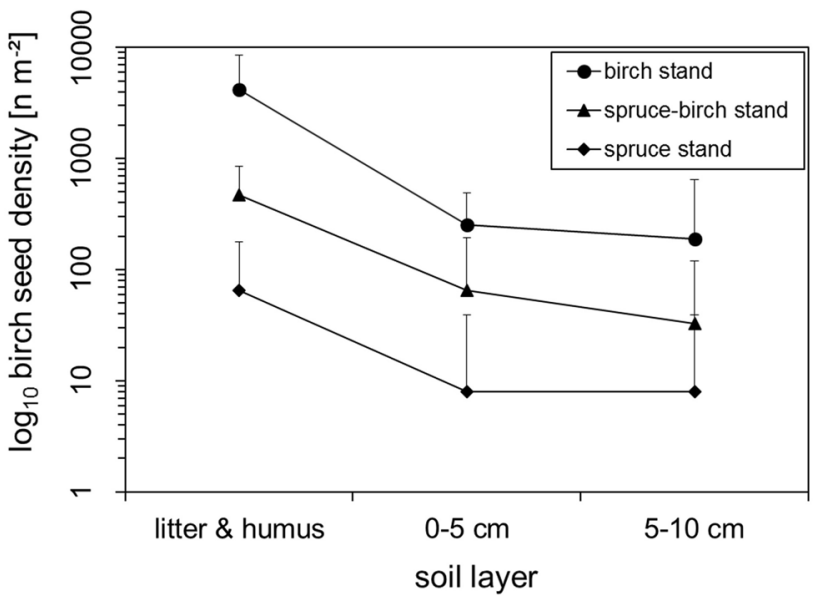

Fig. 2 Mean densities $\left[\mathrm{n} \mathrm{m}^{-2}\right.$ ] with standard deviations of viable Betula pendula seeds present in the seed bank at different soil depths for the stand types. Note the logarithmic scale on the $y$-axis

between the tested effects were also proven and found not to be significant (not shown in Table 2; GLMM: $z=-2.700$ to $1.080, p>0.360)$.

\section{Discussion}

\section{Effect of the number of seed trees}

The varying number of birch seed trees in the stands, ranging from 0 to 8 , was found to be an important factor influencing the amount of viable birch seeds in the humus and mineral soil layers up to a depth of $10 \mathrm{~cm}$ (see first hypothesis). The mean seed density of silver birch in the soil was significantly lower where there were fewer seed trees. A corresponding finding was presented by Bossuyt and Hermy (2001) and Tiebel et al. (2018), which confirmed the importance of the quantity of seed sources. Examples of seed densities of pioneer tree species recorded in European forests are shown in Table 3. The reason for the different seed densities in soil resided in the overlapping seed shadows (= seed rain) of the birch trees in the stands (Paluch 2011; Satoa and Hiurab 1998; Tiebel et al. 2019, 2020). Silver birch begins reproducing at 5-30 years of age and a seed tree can produce up to 10 million seeds in a mast year (Atkinson 1992; Perala and Alm 1990). A strong overlap of the seed rain in pure birch stands, therefore, results in the highest seed numbers deposited on the ground, with correspondingly lower numbers in the mixed spruce and birch stands. In the absence of seed trees, Amrein et al. (2005) and Granström (1982) detected no birch seeds in the soil of deciduous and coniferous forests. The fact that birch seeds were found in the pure spruce stands in this study may have been due to the long dispersal distance, the longest measured for birch being up to $700 \mathrm{~m}$ 
Table 3 Examples of seed densities of wind dispersed pioneer tree species in the soil drawn from European seed bank studies in temperate forests

\begin{tabular}{|c|c|c|c|c|c|c|c|c|c|}
\hline \multirow[t]{2}{*}{ Forest types } & \multirow[t]{2}{*}{ Age [year] } & \multirow{2}{*}{$\begin{array}{l}\text { Month of } \\
\text { sampling }\end{array}$} & \multirow[t]{2}{*}{ Study of litter } & \multirow{2}{*}{$\begin{array}{l}\text { Depth of soil } \\
\text { core }\end{array}$} & \multicolumn{4}{|c|}{ Seed density $\left[\mathrm{n} \mathrm{m}^{-2}\right]$} & \multirow[t]{2}{*}{ Reference } \\
\hline & & & & & Betula ssp. & Salix ssp. & Alnus ssp. & Populus ssp. & \\
\hline \multirow[t]{13}{*}{$\begin{array}{l}\text { Coniferous } \\
\text { forest }\end{array}$} & $43-65$ & February & No & $5 \mathrm{~cm}$ & $1-45$ & Unknown & 0 & 0 & $\begin{array}{l}\text { Augusto et al. } \\
\text { (2001) }\end{array}$ \\
\hline & 53 & June & Yes & $4 \mathrm{~cm}$ & 1039 & 0 & 0 & 0 & $\begin{array}{l}\text { Berger et al. } \\
\text { (2004) }\end{array}$ \\
\hline & 53 & March & Yes & $5 \mathrm{~cm}$ & 728 & 104 & 0 & 0 & $\begin{array}{l}\text { Berger et al. } \\
(2004 a)\end{array}$ \\
\hline & 58 & March & Yes & $5 \mathrm{~cm}$ & 0 & 0 & 0 & 0 & $\begin{array}{l}\text { Berger et al. } \\
\text { (2004) }\end{array}$ \\
\hline & 58 & September & Yes & $5 \mathrm{~cm}$ & 0 & 0 & 0 & 0 & $\begin{array}{l}\text { Berger et al. } \\
\text { (2004) }\end{array}$ \\
\hline & $5-70$ & April & No & $10 \mathrm{~cm}$ & 19-892 & 0 & 0 & 0 & $\begin{array}{l}\text { Dougall and } \\
\text { Dodd (1997) }\end{array}$ \\
\hline & 220 & March & Yes & $10 \mathrm{~cm}$ & 0 & 0 & 0 & 0 & $\begin{array}{l}\text { Ebrecht and } \\
\text { Schmidt } \\
(2008)\end{array}$ \\
\hline & $30-73$ & April & Yes & $6 \mathrm{~cm}$ & $0-912$ & 11 & 0 & 0 & $\begin{array}{l}\text { Granström } \\
\text { (1988) }\end{array}$ \\
\hline & 220 & March & Yes & $20 \mathrm{~cm}$ & $3-14$ & Unknown & Unknown & 0 & $\begin{array}{l}\text { Heinrichs } \\
\text { (2010) }\end{array}$ \\
\hline & 220 & June & No & $10 \mathrm{~cm}$ & 82 & Unknown & Unknown & Unknown & $\begin{array}{l}\text { Jaroszewicz } \\
\text { (2013) }\end{array}$ \\
\hline & Unknown & June & Yes & $10 \mathrm{~cm}$ & $28-121$ & 0 & 0 & 0 & $\begin{array}{l}\text { Komulainen } \\
\text { et al. (1994) }\end{array}$ \\
\hline & Unknown & $\begin{array}{l}\text { July and } \\
\text { August }\end{array}$ & Yes & $5 \mathrm{~cm}$ & 1100 & 0 & 0 & 0 & $\begin{array}{l}\text { Miller and } \\
\text { Cummins } \\
(2003)\end{array}$ \\
\hline & $18-42$ & May and June & Unknown & $15 \mathrm{~cm}$ & $0-509$ & 0 & 0 & 0 & $\begin{array}{l}\text { Warr et al. } \\
\text { (1994) }\end{array}$ \\
\hline
\end{tabular}


Table 3 (continued)

\begin{tabular}{|c|c|c|c|c|c|c|c|c|c|}
\hline \multirow[t]{2}{*}{ Forest types } & \multirow[t]{2}{*}{ Age [year] } & \multirow{2}{*}{$\begin{array}{l}\text { Month of } \\
\text { sampling }\end{array}$} & \multirow[t]{2}{*}{ Study of litter } & \multirow{2}{*}{$\begin{array}{l}\text { Depth of soil } \\
\text { core }\end{array}$} & \multicolumn{4}{|c|}{ Seed density $\left[\mathrm{n} \mathrm{m}^{-2}\right]$} & \multirow[t]{2}{*}{ Reference } \\
\hline & & & & & Betula ssp. & Salix ssp. & Alnus ssp. & Populus ssp. & \\
\hline \multirow[t]{15}{*}{$\begin{array}{l}\text { Deciduous } \\
\text { forest }\end{array}$} & 220 & January & No & $10 \mathrm{~cm}$ & 0 & 0 & 0 & 0 & $\begin{array}{l}\text { Amrein et al. } \\
(2005)\end{array}$ \\
\hline & $57-78$ & February & No & $5 \mathrm{~cm}$ & $0-101$ & 0 & 0 & 0 & $\begin{array}{l}\text { Augusto et al. } \\
\text { (2001) }\end{array}$ \\
\hline & 91 & $\begin{array}{l}\text { March and } \\
\text { September }\end{array}$ & No & $20 \mathrm{~cm}$ & 66 & 0 & 0 & 0 & $\begin{array}{l}\text { Bossuty et al. } \\
(2002)\end{array}$ \\
\hline & 220 & June & No & $20 \mathrm{~cm}$ & 13 and 44 & 0 & 2 and 4 & 0 & $\begin{array}{l}\text { Decocq et al. } \\
\text { (2004) }\end{array}$ \\
\hline & 200 & May & Unknown & $7 \mathrm{~cm}$ & 0 & 0 & 0 & 0 & $\begin{array}{l}\text { Donelan and } \\
\text { Thompson } \\
(1980)\end{array}$ \\
\hline & 220 & April & No & $10 \mathrm{~cm}$ & 134 and 217 & 0 & 0 & 0 & $\begin{array}{l}\text { Dougall and } \\
\text { Dodd (1997) }\end{array}$ \\
\hline & 220 & March & Yes & $10 \mathrm{~cm}$ & 0 & 0 & 0 & 0 & $\begin{array}{l}\text { Ebrecht and } \\
\text { Schmidt } \\
(2008)\end{array}$ \\
\hline & 220 & Early spring & No & $10 \mathrm{~cm}$ & $73 \& 127$ & 0 & 0 & 0 & $\begin{array}{c}\text { Jankowska- } \\
\text { Blaszczuk } \\
\text { et al. (1998) }\end{array}$ \\
\hline & Unknown & $\begin{array}{l}\text { October- } \\
\text { October }\end{array}$ & Unknown & $10 \mathrm{~cm}$ & $20 \& 265$ & 0 & 0 & 0 & $\begin{array}{l}\text { Jedrzejczak } \\
(2013)\end{array}$ \\
\hline & $40-180$ & $\begin{array}{l}\text { March and } \\
\text { April }\end{array}$ & Yes & $17.5 \mathrm{~cm}$ & $0-1,270$ & 0 & $0-354$ & 0 & $\begin{array}{l}\text { Kjellsson } \\
\text { (1992) }\end{array}$ \\
\hline & Unknown & $\begin{array}{c}\text { July and } \\
\text { August }\end{array}$ & Yes & $5 \mathrm{~cm}$ & 2,340 & 0 & 0 & 0 & $\begin{array}{l}\text { Miller and } \\
\text { Cummins } \\
(2003)\end{array}$ \\
\hline & $90-150$ & April & Yes & $5 \mathrm{~cm}$ & $0-195$ & $0-28$ & 0 & 0 & $\begin{array}{l}\text { Staaf et al. } \\
\text { (1987) }\end{array}$ \\
\hline & 220 & $\begin{array}{l}\text { October- } \\
\text { October }\end{array}$ & Yes & $3 \mathrm{~cm}$ & 0 & 0 & 0 & 0 & $\begin{array}{r}\text { Thompson and } \\
\text { Grime (1979) }\end{array}$ \\
\hline & 74 & $\begin{array}{l}\text { October- } \\
\text { October }\end{array}$ & Unknown & $15 \mathrm{~cm}$ & 1,956 & 0 & 0 & 0 & $\begin{array}{l}\text { Warr et al. } \\
\text { (1994) }\end{array}$ \\
\hline & $20-140$ & May and June & Unknown & $15 \mathrm{~cm}$ & $20-3,850$ & 0 & 0 & 0 & $\begin{array}{l}\text { Warr et al. } \\
\text { (1994) }\end{array}$ \\
\hline \multirow[t]{6}{*}{ Mixed forest } & $10-150$ & October & No & $10 \mathrm{~cm}$ & 0 & 0 & 33 & 0 & Kůrová (2016) \\
\hline & 65 & June & Yes & $4 \mathrm{~cm}$ & 156 & 104 & 0 & 0 & $\begin{array}{l}\text { Berger et al. } \\
\text { (2004) }\end{array}$ \\
\hline & 65 & March & Yes & $5 \mathrm{~cm}$ & 0 & 0 & 0 & 0 & $\begin{array}{l}\text { Berger et al. } \\
\text { (2004) }\end{array}$ \\
\hline & 89 & March & Yes & $5 \mathrm{~cm}$ & 0 & 156 & 0 & 0 & $\begin{array}{l}\text { Berger et al. } \\
\text { (2004) }\end{array}$ \\
\hline & 89 & September & Yes & $5 \mathrm{~cm}$ & 0 & 0 & 0 & 0 & $\begin{array}{l}\text { Berger et al. } \\
\text { (2004) }\end{array}$ \\
\hline & 220 & March & Unknown & $5 \mathrm{~cm}$ & $2 \& 80$ & 0 & 0 & 0 & $\begin{array}{c}\text { Jankowska- } \\
\text { Blaszczuk } \\
\text { (1998) }\end{array}$ \\
\hline
\end{tabular}


Table 3 (continued)

\begin{tabular}{|c|c|c|c|c|c|c|c|c|c|}
\hline \multirow[t]{2}{*}{ Forest types } & \multirow[t]{2}{*}{ Age [year] } & \multirow{2}{*}{$\begin{array}{l}\text { Month of } \\
\text { sampling }\end{array}$} & \multirow[t]{2}{*}{ Study of litter } & \multirow{2}{*}{$\begin{array}{l}\text { Depth of soil } \\
\text { core }\end{array}$} & \multicolumn{4}{|c|}{ Seed density $\left[\mathrm{n} \mathrm{m}^{-2}\right]$} & \multirow[t]{2}{*}{ Reference } \\
\hline & & & & & Betula ssp. & Salix ssp. & Alnus ssp. & Populus ssp. & \\
\hline \multirow[t]{14}{*}{ Succession } & $0-80$ & April & No & $10 \mathrm{~cm}$ & $0-160$ & $0-80$ & 0 & 0 & $\begin{array}{l}\text { Bakket et al. } \\
\text { (1996) }\end{array}$ \\
\hline & $7-25$ & March & Unknown & $10 \mathrm{~cm}$ & $24-1,040$ & $0-120$ & $0-216$ & 0 & $\begin{array}{l}\text { Bekker et al. } \\
\text { (2000) }\end{array}$ \\
\hline & $22 \& 36$ & March & No & $30 \mathrm{~cm}$ & $982 \& 646$ & 0 & 0 & 0 & $\begin{array}{l}\text { Dölle and } \\
\text { Schmidt } \\
(2009)\end{array}$ \\
\hline & $50-100$ & May & Unknown & $7 \mathrm{~cm}$ & $0-69$ & 0 & 0 & 0 & $\begin{array}{l}\text { Donelan and } \\
\text { Thompson } \\
(1980)\end{array}$ \\
\hline & $5-20$ & Unknown & Unknown & $3 \mathrm{~cm}$ & $6-1,970$ & $0-350$ & 0-90 & 0 & Falinska (1999) \\
\hline & 220 & July & Yes & $15 \mathrm{~cm}$ & $0 \& 1970$ & Unknown & Unknown & Unknown & Grandin (2001) \\
\hline & 0 & April & Yes & $6 \mathrm{~cm}$ & 11 & 0 & 0 & 0 & $\begin{array}{c}\text { Granström } \\
\text { (1988) }\end{array}$ \\
\hline & 4 & March & Yes & $20 \mathrm{~cm}$ & 3 & Unknown & Unknown & 3 & $\begin{array}{l}\text { Heinrichs } \\
\text { (2010) }\end{array}$ \\
\hline & $17-63$ & May & Yes & $5 \mathrm{~cm}$ & $224-1,810$ & 0 & 0 & 0 & $\begin{array}{l}\text { Hester et al. } \\
\text { (1991) }\end{array}$ \\
\hline & 4 & April & Yes & $10 \mathrm{~cm}$ & 423 & 0 & 0 & 0 & $\begin{array}{l}\text { Hill and Ste- } \\
\text { vens (1981) }\end{array}$ \\
\hline & 20 and 220 & May & No & $10 \mathrm{~cm}$ & $3120 \& 3760$ & 0 & 0 & 0 & $\begin{array}{l}\text { Kalamees and } \\
\text { Zobel (1998) }\end{array}$ \\
\hline & 18 & May & Unknown & $8 \mathrm{~cm}$ & 730 & 0 & 0 & 0 & Milberg (1995) \\
\hline & 31 & February & Unknown & $6.3 \mathrm{~cm}$ & $85-2,534$ & 0 & 0 & 0 & $\begin{array}{l}\text { Mitschell et al. } \\
\text { (1998) }\end{array}$ \\
\hline & 2 & May and June & Unknown & $15 \mathrm{~cm}$ & 305,58 & 0 & 0 & 0 & $\begin{array}{c}\text { Warr et al. } \\
\text { (1994) }\end{array}$ \\
\hline
\end{tabular}

(McEuen and Curran 2004). In those stands in the Tharandter Forest where birch seed trees are absent, there will frequently be birch seed trees found in neighboring stands and along paths. Although an attempt was made to ensure the greatest possible distance between the study stands and the nearest birch seed trees, in most cases the distance to the next seed tree was only $80-100 \mathrm{~m}$. This is well within the range of the mean dispersal distances of 40-360 m (Huth 2009; Tiebel et al. 2020). The distribution of birch seeds in the pure spruce forests by birds like goldfinch, pine siskin and redpoll may be also possible (McAtee 1947). Another reason for the presence of birch seeds in the soil of the pure spruce stands may in some cases have been that birch seed trees were present in the stands up to within a few years of the study taking place. The author found no stumps of birch in the spruce stands, but the possibility cannot be entirely ruled out. If birch seed trees were present up to a few years prior to data collection, their seeds can have remained viable in the soil.

\section{Effect of soil depth}

The factors responsible for the vertical movement of seeds down through the soil layers are largely micro-topography, the size of soil particles, dry cracks in the soil, erosion, frost, rainfall and the activities of soil organisms like earthworms (Moore and Wein 1977; Chambers and MacMahon 1994; Baskin and Baskin 1998; Kollmann 2000; Espinar et al. 2005). Buried seeds are exposed to different storage conditions and predators at different soil depths, so the seed viability rate always decreases with longer storage time, affecting the species-specific seed survival rates (Dalling et al. 1998; Gang et al. 2015; Narwal et al. 2008). Seeds of Betula pendula and Betula pubescence exhibit viability timeframes of between one to more than 13 years depending on soil moisture (Skoglund and Verwijst 1989; Tiebel et al. 2021).

Many studies reported decreasing birch seed densities with deeper soil layers (Godefroid et al. 2006; Hill and 
Stevens 1981; Jaroszewicz 2013; Kalamees and Zobel 1998; Sullivan and Ellison 2006), a finding verified by this study. Due to the input of fresh seed in the annual seed rain, the highest densities of viable birch seeds accumulate in the litter and humus layers (Heinrichs 2010; Hill 1979; Houle 1998). Large numbers of seeds fall but do not germinate, especially in birch mast years (every $2-3$ years), and accumulate on and in the soil (Grisez 1975; Komulainen et al. 1994; Sarvas 1948). The proven influence of 0-8 seed trees per study plot on birch seed density to a depth of $10 \mathrm{~cm}$ in the soil confirmed the results obtained by Komulainen et al. (1994). Higher seed densities were found at all soil depths with an increasing number of seed trees, as assumed in the first hypothesis, although it cannot be said whether there had been a mast year or not. As the seedlings that emerged from the soil samples originated from seed rains produced over numerous years, the question of whether the study took place in a mast or non-mast year is of minor importance in this context. Where there is a high stocking density of birch seed trees in a stand, with overlapping seed shadows, high numbers of seeds are deposited on the ground annually (also in non-mast years). A portion of these seeds reaches the soil and so the soil seed bank is continuously refreshed in all layers.

Nevertheless, for all stands the numbers of birch seeds found decreased with increasing soil depth. During the slow vertical drift into deeper soil (Burmeier et al. 2010; Granström 1982, 1988; van Tooren 1988), birch seeds are subjected to fungal pathogens, decay, attacks by insects and other predators, or they become necrotic (O'HanlonManners and Kotanen 2006; Schwienbacher and Erschbamer 2001). These influences cause the seeds to lose their viability. Sarvas (1952) claimed that birch seeds decompose in the soil over a period of 5-7 years, while Granström (1987) found partly degraded and viable birch seeds in the soil after 5 years' storage. To maintain a birch seed bank in the soil, every few years replenishment facilitated by several trees is necessary (Tiebel et al. 2021).

\section{Effect of ground cover}

Variation in ground cover density and humus thickness played no role in the amount of birch seeds in the different stand types and soil layers, refuting the second hypothesis. None of the factors considered inhibited or intensified movement of birch seeds into the soil seed bank.

The litter was no physical barrier to the vertical movement of birch seeds and the development of a soil seed bank. This contradicted the findings of Facelli and Pickett (1991) and Yan et al. (2013), while supporting those of Bueno and Baruch (2011) and Gang et al. (2015).

Litter, on the other hand, prevented germination of seed of light-demanding species due to shading. Seed viability is, therefore, maintained (Gang et al. 2015), but this effect could not be proven in this study. On open areas an increase in the litter and moss cover, and an increase in the depth of each layer, should serve to attenuate the effect of temperature extremes, higher soil moisture, lower light levels, predation and movement, helping to maintain seed viability (Donath and Eckstein 2010; Egawa and Tsuyuzaki 2013). However, no effect of litter and moss cover was identified in this study, which may have been connected to the fact that it was performed in the forest. Canopy trees in closed forest create the same climate effects that litter and moss cover produce on open areas (Bartsch et al. 2020).

Grass and herbs did not inhibit the formation of birch soil seed banks in forest stands either. The gaps between the individual herbs and grasses were sufficient to allow small birch seeds to reach the ground. Generally, grassland seed banks exhibit high species richness, seed density and similarity between the soil seed bank community and the vegetation composition (Hopfensberger 2007). Consequently, large amounts of seeds are deposited between grass and herbs on the soil surface and reach the soil, independent of the landscape.

\section{Conclusions}

Forest regeneration from soil seed banks becomes important in situations where stands are destroyed by large-scale disturbance events, such as strong winds or fire (Fenner 1985; Dalling et al. 1998; Berger et al. 2004; de Andrade et al. 2014). Where disturbance events affect large areas, not only are seed trees missing from the immediate site, but regeneration by means solely of seed rain may fail.

The results of the soil core sampling in the Tharandter Forest showed a significant relationship between the numbers of seed tree sources in the stands and the densities of viable birch seed in the soil. Successful rapid regeneration of birch from the soil seed bank is guaranteed in birch stands and spruce-birch stands, as assumed in the first hypothesis. Low seed tree densities lead to low birch seed reserves in the soil and to insufficient replenishment of these reserves. This increases forest manager uncertainty when it comes to estimating the likely extent of natural regeneration. Commercial forests must be reforested within a legally prescribed period of 3 to 6 years in Germany. Successful regeneration of a site following disturbance driven by the soil seed bank (1) requires the presence of birch seed tress in the stand before the event and (2) the presence of birch seed trees in the stands adjacent to the previous stands of pure spruce. If the duration of the regeneration process does not matter, a low seed density of birch does not necessarily mean that birch cannot over time establish a pioneer forest. 
The degree of ground cover and the accumulation of litter in the stands had no influence on the formation of the seed bank, refuting the second hypothesis, and can, therefore, be neglected in the assessment of the regeneration potential from the soil.

Acknowledgements I would like to thank Katja Skibbe, Antje Karge and Angelika Otto for assistance in the greenhouse. I thank David Butler Manning for proofreading the text.

Funding Open Access funding enabled and organized by Projekt DEAL.

\section{Declarations}

Conflict of interest The author declares that she has no conflict of interest.

Open Access This article is licensed under a Creative Commons Attribution 4.0 International License, which permits use, sharing, adaptation, distribution and reproduction in any medium or format, as long as you give appropriate credit to the original author(s) and the source, provide a link to the Creative Commons licence, and indicate if changes were made. The images or other third party material in this article are included in the article's Creative Commons licence, unless indicated otherwise in a credit line to the material. If material is not included in the article's Creative Commons licence and your intended use is not permitted by statutory regulation or exceeds the permitted use, you will need to obtain permission directly from the copyright holder. To view a copy of this licence, visit http://creativecommons.org/licenses/by/4.0/.

\section{References}

Amrein D, Rusterholz H-P, Baur B (2005) Disturbance of suburban Fagus forests by recreational activities: effects on soil characteristics, aboveground vegetation and seed bank. Appl Veg Sci 8:175-182. https://doi.org/10.1658/1402-2001(2005)008[0175: DOSFFB]2.0.CO;2

Atkinson MD (1992) Betula pendula Roth (B. verrucosa Ehrh.) and B. pubescens Ehrh. J Ecol 80:837-870. https://doi.org/10.2307/ 2260870

Augusto L, Dupouey J-L, Picard J-F, Ranger J (2001) Potential contribution of the seed bank in coniferous plantations to the restoration of native deciduous forest vegetation. Acta Oecol 22:87-98. https://doi.org/10.1016/S1146-609X(01)01104-3

Bakker JP, Bakker ES, Rosén E, Verwej GL, Bekker RM (1996) Soil seed bank composition along a gradient from dry alvar grassland to Juniperus shrubland. J Veg Sci Sci 7:165-176. https://doi.org/ $10.2307 / 3236316$

Bartsch N, von Lüpke B, Röhrig E (2020) Waldbau auf ökologischer Grundlage. Eugen Ulmer KG, Stuttgart

Baskin CC, Baskin JM (1998) Seeds-ecology, biogeography, and evolution, of dormancy and germination. Academic Press, San Diego

Bekker RM, Verwej GL, Bakker JP, Fresco LFM (2000) Soil seed bank dynamics in hayfield succession. J Ecol 88:594-607. https://doi. org/10.1046/j.1365-2745.2000.00485.x

Berger TW, Sun B, Glatzel G (2004) Soil seed banks of pure spruce (Picea abies) and adjacent mixed species stands. Plant Soil
264:53-67. https://doi.org/10.1023/B:PLSO.0000047753.36424. 41

Bolker B, Skaug H, Magnusson A, Nielsen A (2012) Getting started with the glmmADMB package. http://glmmadmb.r-forge.r-proje ct.org/glmmADMB.pdf Accessed 11 Feb 2019

Bossuyt B, Hermy M (2001) Influence of land use history on seed banks in European temperate forest ecosystems: a review. Ecography 24:225-238. https://doi.org/10.1034/j.1600-0587.2001. 240213.x

Bossuyt B, Heyn M, Hermy M (2002) Seed bank and vegetation composition of forest stands of varying age in central Belgium: consequences for regeneration of ancient forest vegetation. Plant Ecol 162:33-48. https://doi.org/10.1023/A:1020391430072

Brouwer W, Stählin A (1975) Handbuch der Samenkunde für Landwirtschaft. DLG-Verlags-GmbH, Frankfurt (Main)

Bueno A, Baruch Z (2011) Soil seed bank and the effect of needle litter layer on seedling emergence in a tropical pine plantation. Rev Biol Trop 59:1071-1079

Burmeier S, Eckstein RL, Otte A, Donath TW (2010) Desiccation cracks act as natural seed traps in flood-meadow systems. Plant Soil 333:351-364. https://doi.org/10.1007/s11104-010-0350-1

Chambers JC, MacMahon JA (1994) A day in the life of a seed: movements and fates of seeds and their implications for natural and managed systems. Annu Rev Ecol Syst 25:263-292. https://doi.org/10.1146/annurev.es.25.110194.001403

Dalling JW, Swaine MD, Garwood NC (1998) Dispersal patterns and seed bank dynamics of pioneer trees in moist tropical forest. Ecology 79:564-578. https://doi.org/10.1890/0012-9658(1998) 079[0564:DPASBD]2.0.CO;2

de Andrade LAZ, Miranda HS (2014) The dynamics of the soil seed bank after a fire event in a woody savanna in central Brazil. Plant Ecol 215:1199-1209. https://doi.org/10.1007/ s11258-014-0378-z

Decocq G, Valentin B, Toussaint B, Hendoux F, Saguez R, Bardat J (2004) Soil seed bank composition and diversity in a managed temperate deciduous forest. Biodivers Conserv 13:2485-2509. https://doi.org/10.1023/B:BIOC.0000048454.08438.c6

Dierschke H (1994) Pflanzensoziologie-Grundlagen und Methoden. Verlag Eugen Ulmer, Stuttgart

Dölle M, Schmidt W (2009) The relationship between soil seed bank, above-ground vegetation and disturbance intensity on old-field successional permanent plotsAppl. Veg Sci 12:415-428. https:// doi.org/10.1111/j.1654-109X.2009.01036.X

Donath TW, Eckstein RL (2010) Effects of bryophytes and grass litter on seedling emergence vary by vertical seed position and seed size. Plant Ecol 207:257-268. https://doi.org/10.1007/ s11258-009-9670-8

Donelan M, Thompson K (1980) Distribution of buried viable seeds along a successional series. Biol Conserv 17:297-311. https:// doi.org/10.1016/0006-3207(80)90029-4

Dougall TAG, Dodd JC (1997) A study of species richness and diversity in seed banks and its use for the environmental mitigation of a proposed holiday village development in a coniferized woodland in south east England. Biodivers Conserv 6:1413-1428

Ebrecht L, Schmidt W (2008) Bedeutung der Bodensamenbank und des DiasporentransportsdurchForstmaschinenfür die Entwicklung der Vegetation auf Rückegassen Forstarchiv 79:91-105

Egawa C, Tsuyuzaki S (2013) The effects of litter accumulation through succession on seed bank formation for small and large seeded species. J Veg Sci 24:1062-1073. https://doi.org/10.1111/ jvs. 12037

Espinar JL, Thompson K, García LV (2005) Timing of seed dispersal generates a bimodal seed bank depth distribution. Am J Bot 92:1759-1763. https://doi.org/10.3732/ajb.92.10.1759 
Facelli JM, Pickett STA (1991) Plant litter: its dynamics and effects on plant community structure. Bot Rev 57:1-32. https://doi.org/ 10.1007/BF02858763

Falinska K (1999) Seed bank dynamics in abandoned meadows during a 20-year period in the Białowieża National Park. J Ecol 87:461-475. https://doi.org/10.1046/j.1365-2745.1999.00364.x

Fenner M (1985). Seed ecology. Chapman and Hall Ltd, London and New York, UK and USA

Fiedler HJ, Hofmann W (1978) Standortskundlicher Exkursionsführer ,Tharandt-Grillenburger Wald“--Bodennutzung und Bodenschutz. Studienmaterial für die Weiterbildung. TU Dresden-Direktion Studienangelegenheiten, Dresden

Gage EA, Cooper DJ (2005) Patterns of willow seed dispersal, seed entrapment, and seedling establishment in a heavily browsed montane riparian ecosystem. Can J Bot 83:678-687. https://doi. org/10.1139/B05-042

Gang Q, Yan Q, Zhu J (2015) Effects of thinning on early seed regeneration of two broadleaved tree species in larch plantations: implication for converting pure larch plantations into larchbroadleaved mixed forests. Forestry 88:573-585. https://doi.org/ 10.1093/forestry/cpv025

Godefroid S, Phartyal SS, Koedam N (2006) Depth distribution and composition of seed banks under different tree layers in a managed temperate forest ecosystem. Acta Oecol 29:283-292. https://doi.org/10.1016/j.actao.2005.11.005

Goldberg V, Baums AB, Häntzschel J (2002) Klima, Boden und Landnutzung. In: Bernhofer C, Berger FH, Goldberg V (eds): Exkursions- und Praktikumsführer Tharandter Wald. Tharandter Klimaprotokolle Band 6. Eigenverlag der Technischen Universität Dresden, Dresden, pp 15-26

Grandin U (2001) Short-term and long-term variation in seed bank/ vegetation relations along an environmental and successional gradient. Ecography 24:731-741. https://doi.org/10.1111/j.16000587.2001.tb00534.x

Granström A (1982) Seed banks in five boreal forest stands originating between 1810 and 1963. Can J Bot 60:1815-1821. https://doi. org $/ 10.1139 / \mathrm{b} 82-228$

Granström A (1987) Seed viability of fourteen species during five years of storage in a forest soil. J Ecol 75:321-331. https://doi.org/10. $2307 / 2260421$

Granström A (1988) Seed banks at six open and afforested heathland sites in southern Sweden. J Appl Ecol 25:297-306. https://doi. org/10.2307/2403627

Grisez T (1975) Flowering and seed production in seven hardwood species. Northeastern Forest Experiment Station, Forest Service Research Paper NE-315, Upper Darby, USA

Gross KL (1990) A Comparison of methods for estimating seed numbers in the soil. J Ecol 78:1079-1093. https://doi.org/10.2307/ 2260953

Heinrichs S (2010) Response of the understorey vegetation to select cutting and clear cutting in the initial phase of Norway spruce conservation. PhD thesis, Faculty of Mathematics and Natural Sciences, Georg-August-University Göttingen, Göttingen

Hester AJ, Gimingham CH, Miles J (1991) Succession from heather moorland to birch woodland. III. Seed availability, germination and early growth. J Ecol 79:329-344. https://doi.org/10.2307/ 2260716

Hill MO (1979) The development of a flora in even-aged plantations. In: Ford ED, Malcolm DC, Atterson J (eds) The ecology of evenaged forest plantations. Institute of Terrestrial Ecology, Cambridge, pp 175-192

Hill MO, Stevens PA (1981) The density of viable seed in soils of forest plantations in upland Britain. J Ecol 69:693-709. https://doi. org/10.2307/2259692
Hille Ris Lambers J, Clark JS, Lavine M (2005) Implications of seed banking for recruitment of southern Appalachian woody species. Ecology 86:85-95. https://doi.org/10.1890/03-0685

Hopfensperger KN (2007) A review of similarity between seed bank and standing vegetation across ecosystems. Oikos 116:14381448. https://doi.org/10.1111/j.2007.0030-1299.15818.x

Houle G (1998) Seed dispersal and seedling recruitment of Betula alleghaniensis: spatial inconsistency in time. Ecology 79:807818. https://doi.org/10.1890/0012-9658(1998)079[0807: SDASRO]2.0.CO;2

Huth F (2009) Untersuchungen zur Verjüngungsökologie der SandBirke (Betula pendula Roth). PhD thesis, Faculty of Forest, Geo and Hydro, Dresden University of Technology, Dresden

IPCC (2014) Climate change: impacts, adaptation, and vulnerability. intergovernmental panel on climate change, Assessment Report 5, Cambridge University Press, New York

IPCC (2020) Climate change and land: special report on climate change, desertification, land degradation, sustainable land management, food security, and greenhouse gas fluxes in terrestrial ecosystems. IPCC web. https://www.ipcc.ch/site/assets/uploads/ sites/4/2020/02/SPM_Updated-Jan20.pdf Accessed 18 February 2021

Jankowska-Błaszczuk M (1998) Variability of the soil seed banks in the natural deciduous forest in the Białowieża National Park. Acta Soc Bot Pol 67:313-324. https://doi.org/10.5586/asbp.1998.040

Jankowska-Błaszczuk M, Kwiatkowska AJ, Panufnik D, Tanner E (1998) The size and diversity of the soil seed banks and the light requirements of the species in sunny and shady natural communities of the Białowieża Primeval Forest. Plant Ecol 136:105-118. https://doi.org/10.1023/A:1009750201803

Jaroszewicz B (2013) Endozoochory by European bison influences the build-up of the soil seed bank in subcontinental coniferous forest. Eur J Forest Res 132:445-452. https://doi.org/10.1007/ s10342-013-0683-4

Jędrzejczak E (2013) Soil seed bank in selected patches of vegetation in the beech forest of BeskidŚląski (Southern Poland). Čas Slez Zemského Muz 62:137-150. https://doi.org/10.2478/ cszma-2013-0015

Jordano P, Schupp EW (2000) Seed disperser effectiveness: the quantity component and patterns of seed rain for Prunus mahaleb. Ecol Monogr 70:591-615

Kalamees R, Zobel M (1998) Soil seed bank composition in different successional stages of a species rich wooded meadow in Laelatu, Western Estonia. Acta Oecol 19:175-180. https://doi.org/10. 1016/S1146-609X(98)80021-0

Kjellsson G (1992) Seed banks in Danish deciduous forests: species composition, seed influx and distribution pattern in soil. Ecography 15:86-100. https://doi.org/10.1111/j.1600-0587.1992.tb000 12.x

Knocke T, Ammer C, Stimm B, Mosandl R (2008) Admixing broadleaved to coniferous tree species: a review on yield, ecological stability and economics. Eur J Forest Res 127:89-101. https:// doi.org/10.1007/s10342-007-0186-2

Kollmann J (2000) Dispersal of fleshy-fruited species: a matter of spatial scale? Perspect Plant Ecol Evol Syst 3:29-51. https://doi.org/ 10.1078/1433-8319-00003

Komulainen M, Vieno M, Yarmishko VT, Daletskaja TD, Maznaja EA (1994) Seedling establishment from seeds and seed banks in forests under long-term pollution stress: a potential for vegetation recovery. Can J Bot 72:143-149. https://doi.org/10.1139/b94-019

Kramer H, Akça A (2002) Leitfaden zur Waldmesslehre. D. Sauerländers Verlag, Frankfurt am Main

Kůrová J (2016) The impact of soil properties and forest stand age on the soil seed bank. Folia Geobot 51:27-37. https://doi.org/10. 1007/s12224-016-9236-1 
Liu X, He Y, Xiao Y, Wang Y, Jiang Y, Jiang Y (2019) Soil seed burial and competition with surrounding plants determine the emergence and development of seedling of an endangered species Horsfieldia hainanensis Merr. in China. Sci Rep 9:17970. https://doi.org/10.1038/s41598-019-54644-7

Ma Q, Huang J-G, Hänninen H, Berninger F (2017) Divergent trends in the risk of spring frost damage to trees in Europe with recent warming. Glob Change Biol 25:351-360. https://doi.org/10. $1111 /$ gcb. 14479

McAtee WL (1947) Distribution of seeds by birds. Am Midl Nat 38:214-223. https://doi.org/10.2307/2421637

McEuen AB, Curran LM (2004) Seed dispersal and recruitment limitation across spatial scales in temperate forest fragments. Ecol 85:507-518. https://doi.org/10.1890/03-4006

Menzer A, Feger K-H, Lohse H, Joisten H, Hurst S (2010) Bodenlehrpfad Tharandter Wald - Exkursionsführer. Sächsisches Landesamt für Umwelt, Landwirtschaft und Geologie, Dresden

Milberg P (1995) Soil seed bank after eighteen years of succession from grassland to forest. Oikos 72:3-13. https://doi.org/10.2307/ 3546031

Miller GR, Cummins RP (2003) Soil seed banks of woodland, heathland, grassland, mire and montane communities, Cairngorm Mountains, Scotland. Plant Ecol 168:255-266. https://doi.org/ 10.1023/A:1024464028195

Mitschell RJ, Marrs RH, Auld MHD (1998) A comparative study of the seedbanks of heathland and successional habitats in Dorset, Southern England. J Ecol 86:588-596. https://doi.org/10.1046/j. 1365-2745.1998.00281.x

Moore JM, Wein RW (1977) Viable seed populations by soil depth and potential site recolonization after disturbance. Can J Bot 55:2408-2412. https://doi.org/10.2307/3546031

Narwal S, Sindel BM, Jessop RS (2008) Dormancy and longevity of annual ryegrass (Lolium rigidum) as affected by soil type, depth, rainfall, and duration of burial. Plant Soil 310:225-234. https:// doi.org/10.1007/s11104-008-9649-6

Nebe W (1982) Natürliche Grundlagen des Waldwachstums und der Waldentwicklung. Der Tharandter Wald. Forststadt Tharandt Beitrag zur Heimatgeschichte 7/82, Gemeindeverband Tharandt

O'Hanlon-Manners DL, Kotanen PM (2006) Losses of seeds of temperate trees to soil fungi: effects of habitat and host ecology. Plant Ecol 187:49-58. https://doi.org/10.1007/s11258-006-9132-5

Olano JM, Caballero I, Laskurain NA, Loidi J, Escudero A (2002) Seed bank spatial pattern in a temperate secondary forest. J Veg Sci 13:775-784. https://doi.org/10.1111/j.1654-1103.2002.tb02107.x

Paluch JG (2011) Ground seed density patterns under conditions of strongly overlapping seed shadows in Abies alba Mill. stands. Eur J Forest Res 130:1009-1022. https://doi.org/10.1007/ s10342-011-0486-4

Perala DA, Alm AA (1990) Reproductive ecology of birch: a review. Forest Ecol Manag 32:1-38. https://doi.org/10.1016/03781127(90)90104-J

Plohak P, Svehlakova H, Rajdus T, Stalmachova B (2020) Soil seed bank in Ostrava post-mining landscape. IOP Conf Ser Earth Environ Sci 444:012044. https://doi.org/10.1088/1755-1315/ 444/1/012044

Pugnaire FI, Lozano J (1997) Effects of soil disturbance, fire and litter accumulation on the establishment of Cistus clusii seedlings. Plant Ecol 131:207-213. https://doi.org/10.1023/A:1009779820 845

Putz FE, Appanah S (1987) Buried seeds, newly dispersed seeds, and the dynamics of a lowland forest in Malaysia. Biotropica 19:326333. https://doi.org/10.2307/2388630

R Core Team (2014) R: A language and environment for statistical computing. R Foundation for Statistical Computing, Vienna. https://www.R-project.org Accessed 11 Feb 2019
Sarvas R (1948) A research on the regeneration of birch in South Finland. Commun Inst for Fenn 35:82-91

Sarvas R (1952) On the flowering of birch and the quality of seed crop. Commun Inst for Fenn 40:1-35

Satoa H, Hiurab T (1998) Estimation of overlapping seed shadows in a northern mixed forest. Forest Ecol Manag 104:69-76. https:// doi.org/10.1016/S0378-1127(97)00247-8

Schwanecke W, Kopp D (1996) Forstliche Wuchsgebiete und Wuchsbezirke im Freistaat Sachsen. Schriftenreihe der Sächsischen Landesanstalt für Forsten 8/96

Schwiebus A, Baums AB (2002) Lage, Geologie und Geschichte. In: Bernhofer C, Berger FH, Goldberg V (eds) Exkursions- und Praktikumsführer Tharandter Wald. Eigenverlag der Technischen Universität Dresden, Dresden, pp 9-14

Schwienbacher E, Erschbamer B (2001) Longevity of seeds in a glacier foreland of the Central Alps-A burial experiment. Bull Geobot Inst ETH 68:63-71

Skoglund J, Verwijst T (1989) Age structure of woody species populations in relation to seed rain, germination and establishment along the river Dalälven, Sweden. Vegetation 82:25-34. https://doi.org/10.1007/BF00217979

Staaf H, Jonsson M, Olsén L-G (1987) Buried germinative seeds in mature beech forests with different herbaceous vegetation and soil types. Holarctic Ecol 10:268-277. https://doi.org/10. 1111/j.1600-0587.1987.tb00768.x

Sullivan KA, Ellison AM (2006) The seed bank of hemlock forests: implications for forest regeneration following hemlock decline. J Torrey Bot Soc 133:393-402

Thompson K, Grime JP (1979) Seasonal variation in the seed banks of herbaceous species in ten contrasting habitats. J Ecol 67:893-921. https://doi.org/10.2307/2259220

Tiebel K, Huth F, Wagner S (2018) Soil seed banks of pioneer tree species in European temperate forests: a review. iForest 11:48-57

Tiebel K, Huth FN, Wagner S (2020) Restrictions on natural regeneration of storm-felled spruce sites by silver birch (Betula pendula Roth) through limitations in fructification and seed dispersal. Eur J For Res online. https://doi.org/10.1007/s10342-020-01281-9

Tiebel K, Huth F, Wagner S (2021) Is there an effect of storage depth on the persistence of silver birch (Betula pendula Roth) and rowan (Sorbus aucuparia L.) seeds? Seed Burial Exper Iforest 14:224-230. https://doi.org/10.3832/ifor3685-014

Tiebel K, Karge A, Huth F, Wehnert A, Wagner S (2017) Strukturelemente fördern die Samenausbreitung durch Vögel. AFZ-Der Wald 20:24-27

Tiebel K, Leinemann L, Hosius B, Schlicht R, Frischbier N, Wagner S (2019) Seed dispersal capacity of Salix caprea L. assessed by seed trapping and parentage analysis. Eur J Forest Res 138:495511. https://doi.org/10.1007/s10342-019-01186-2

Van TK, Rayamajhi MB, Center TD (2005) Seed longevity of Melaleuva quinquenervia: a burial experiment in South Florida. J Aquat Plant Manage 43:39-42

van Tooren BF (1988) The fate of seeds after dispersal in chalk grassland: the role of the bryophyte layer. Oikos 53:41-48. https://doi. org/10.2307/3565661

Wallraf A, Wagner S (2019) Effects of initial plant density, interspecific competition, tending and age on the survival and quality of oak (Quercus robur L.) in young mixed stands in European Russia. For Ecol Manag 446:272-284. https://doi.org/10.1016/j.foreco. 2019.05.037

Warr SJ, Kent M, Thompson K (1994) Seed bank composition and variability in five woodlands in South-West England. J Biogeogr 21:151-168. https://doi.org/10.2307/2845469

Weerasinghe M, Ashton MS, Hooper ER, Singhakumara BMP (2019) Floristics of soil seed banks on agricultural and disturbed land 
cleared of tropical forests. Restor Ecol 27:138-147. https://doi. org $/ 10.1111 /$ rec. 12711

Yan Q, Zhu J, Gang Q (2013) Comparison of spatial patterns of soil seed banks between larch plantations and adjacent secondary forests in Northeast China: implication for spatial distribution of larch plantations. Tress 27:1747-1754

Zar JH (2010) Biostatistical analysis, 5th edn. Prentice Hall, Upper Saddle River, New Jersey

Zerbe S (2001) On the ecology of Sorbus aucuparia (Rosaceae) with special regard to germination, establishment and growth. Pol Bot J 46:229-239

Zerbe S (2009) Renaturierung von Waldökosystemen. In: Zerbe S, Wiegleb G (eds) Renaturierung von ökosystemen in mitteleuropa.
Spektrum Akademischer Verlag, Heidelberg, Germany, pp 153-182

Zuur AF, Ieno EN, Walker NJ, Saveliev A, Smith GM (2009) Mixed effects and extensions in ecology with R. Springer Science and Business Media, New York

Publisher's Note Springer Nature remains neutral with regard to jurisdictional claims in published maps and institutional affiliations. 